\title{
INFLUENCE OF FOOD INTAKE ON THE 24-hr VARIATIONS OF PLASMA IRON CONCENTRATION IN THE RABBIT
}

\author{
Klaus Schümann and Ekkehard Haen
}

\begin{abstract}
Walther Straub-Institut für Pharmakologie und Toxikologie der Ludwig-Maximilians-Universität München, 8 München 2, Nußbaumstraße 26, Federal Republic of Germany
\end{abstract}

(First received December 1986, accepted in revised form April 1987)

\begin{abstract}
Circadian variations in plasma iron levels were first reported in humans in 1937. Influences of the sleeping pattern and of plasma cortisol and adrenalin levels on these variations as well as the reproducibility of the phenomenon itself are discussed controversially in the literature. The influence of food intake, however, was not considered in most of the studies and is therefore subject of this investigation.

Circadian plasma iron and plasma transferrin variations were determined in rabbits and compared under free access to food and under starvation (caecothrophy was not prevented). Population-mean-cosinor analysis of circadian plasma iron concentrations showed similar variations in the fed and starved condition (mesor: $116.6 \mu \mathrm{g} / \mathrm{d}$ ] vs $118.1 \mu \mathrm{g} / \mathrm{dl}$, acrophase $0752 \mathrm{hr}$ vs 0728 ) except for a significant increase of the circadian amplitude under free access to food $(30.9 \mu \mathrm{g} / \mathrm{dl}$ vs $22.3 \mu \mathrm{g} / \mathrm{dl}, \boldsymbol{P}<0.05)$. There was no variation in plasma transferrin, which shows that $24 \mathrm{hr}$ variations in plasma iron are not caused by modulation of plasma transferrin. These findings demonstrate a circadian rhythm for plasma iron, the amplitude of which is increased by food intake.
\end{abstract}

Key words-Circadian, plasma iron, food intake, rabbits.

\section{Introduction}

A circadian rhythm of plasma iron in men with lowest concentrations between 1800 and 2400 was first described about 50 years ago (1-3). Changes in this pattern during night shifts were observed (4) and connected to the sympathicotonus (5) as well as to influences of the reticulo-hypothalamic system (6). The idea of sympathetic influences on plasma iron was objected by Hamilton (7) in 1950, who in turn found a relationship between plasma iron concentrations and the adrenocortical function in dogs and cats. Paterson, however, showed that neither adrenalin, nor ACTH nor cortisol had any impact on the $24 \mathrm{hr}$ fall and rise of plasma iron, neither in healthy humans nor in Addison's disease (8).

Not only that the attempts to explain circadian changes in plasma iron levels remained unsatisfactory, even the phenomenon itself was not consistently found. Bowie (9) did not observe any consistent pattern in the $24 \mathrm{hr}$ variations of plasma iron in 11 humans, while Wiltink (10) described maximal plasma iron values in the late afternoon in 13 cases, which is $180^{\circ}$ out of phase to earlier observations. A Gaussian distribution of the range of circadian plasma iron variations was described as early as 1944 by Höyer (4). With the exception of Wiltink (10) who administered a standa rdized diet every $4 \mathrm{hr}$ to two volunteers as a set of controls, the aspect of food intake and its periodicity was not considered in any of these studies.

The total plasma iron content amounts to about $7 \mathrm{mg}$ in healthy men. This seems negligible compared to body iron stores containing roughly $1 \mathrm{~g}$. One to $2 \mathrm{mg}$ of iron are daily absorbed from the $10-20 \mathrm{mg}$ a normal western diet contains (11), which is equivalent to roughly $25 \%$ of total plasma iron. Thus, two major sources of influence on the plasma iron level must be considered: iron-absorption (12) and reticuloendothelial iron uptake and release (13). When iron-deficient animals were compared with normal controls both of these factors were found to depend la rgely on the size of body iron stores, which had not been determined in the studies summarized above.

This study investigates the $24 \mathrm{hr}$ variations of 
plasma iron in rabbits. They are the smallest laboratory animals that allow the necessary blood sampling for intraindividual comparison over $24 \mathrm{hr}$ without severely depleting body iron stores. The $24 \mathrm{hr}$ variations of plasma iron were examined under free access to food and under food deprivation. The results were related to body iron stores. The paper shall contribute to the discussion on the factors responsible for the circadian variations of plasma iron concentrations.

\section{Material and Methods}

Six adult male rabbits (Groß-Chinchillas, Riedl, München, FRG; weight $3.8-4.6 \mathrm{~kg}$ ) were housed individually on stainless steel grids under L:D = $12: 12$ (lights on 0630-1830), constant temperature $\left(22^{\circ} \mathrm{C}\right)$ and humidity $(60 \%)$. The animals were allowed to adapt to their environment for 4 weeks. The study was performed in February/ March with all animals at the same time. Body weights are listed in Table 1. The animals were kept on a diet (Diet H 4000, Botzenhardt KG, Kempten, FRG) supplemented with $50 \mathrm{mg} / \mathrm{kg}$ of iron and $5 \mathrm{mg} / \mathrm{kg}$ of copper, fed ad libitum. Caecotrophy was not prevented. Tap water was available ad libitum.

In the first experiment $2 \mathrm{ml}$ of blood were drawn from the ear-veins at $6 \mathrm{hr}$ intervals $(1200$, $1800,2400,0600,1200)$ via a preexperimentaly inserted canula, while the animals had free access to food and tap-water. A second experiment was performed two weeks later in the same animals following the same schedule and procedure except that the animals had been without food for $24 \mathrm{hr}$ prior to as well as during the experiment

Table 1. Individual data for body weight, $\mathrm{Hb}$ and liver non-heme iron (day of sacrifice, $9.00 \mathrm{hr}$ )

\begin{tabular}{cccc}
\hline No. & $\begin{array}{c}\text { Body weight } \\
(\mathrm{g})\end{array}$ & $\begin{array}{c}\text { Haemoglobin } \\
(\mathrm{g} / 100 \mathrm{ml})\end{array}$ & $\begin{array}{c}\text { Liver non-heme iron } \\
(\mu \mathrm{g} / \mathrm{g} \text { ww })\end{array}$ \\
\hline 1 & 4630 & 9.3 & 580 \\
2 & 3780 & 8.6 & 128 \\
3 & 4060 & 9.0 & 184 \\
4 & 3965 & 10.3 & 462 \\
5 & 3810 & 10.8 & 613 \\
6 & 3915 & 9.3 & 277 \\
\hline
\end{tabular}

(48 $\mathrm{hr}$ without food altogether). During this time only demineralized water was available ad libitum.

The plasma iron content and in two animals the free iron binding capacity were determined photometrically using a standardized test kit (Merckotest No.3317 and No.3313, Merck, Hohenbrunn, FRG) based on the ironbathophenantrolin reaction. Plasma transferrin was determined quantitatively under free access to food by means of Mancini's radial immunodiffusion (anti-rabbit transferrin from goat (0112-1414), Cooper Biomedical, Frankfurt/M, FRG). Haemoglobin values were measured at $0900 \mathrm{hr}$ on the day of sacrifice according to the cyan-haemoglobin method. Non-heme-iron was determined in liver-tissue after the animals were sacrificed at 1200 . Determination followed the procedure described by El-Shobaki (14) $(6 \%$ liver tissue homogenates, extraction of nonheme-iron by $\mathrm{HCl}\left(4.25 \mathrm{~N}, \mathrm{l} \mathrm{hr}, 90^{\circ} \mathrm{C}\right)$, photometric quantification $(546 \mathrm{~nm})$ of the irondipyridil complex). As appropriate blancs had shown, iron contamination was successfully avoided by use of plastic material and by decontaminating glass ware with nitric acid.

All reagents used were of p.a. grade and purchased from Merck, Hohenbrunn, FRG and Sigma, München, FRG.

The $24 \mathrm{hr}$ variations were statistically validated by means of an analysis of variance (ANOVA) as well as by single cosinor and population mean cosinor analysis $(15)(P<0.05$ was regarded as significant). The differences of circadian amplitudes with and without access to food were tested by Student's $t$-test.

\section{Results}

Individual body weights, $\mathrm{Hb}$ and liver nonheme iron are given in Table 1.; Table 2. shows the correlation between non-heme iron on the one hand and transferrin, $\mathrm{Hb}$, as well as circadian plasma iron mesor and amplitude on the other hand.

Individual plasma iron values under free access to food are depicted in Figure 1A. The animals showed similar patterns with high values 
Table 2. Correlation coefficients ( $r$ )

\begin{tabular}{lcccccc}
\hline & $\begin{array}{c}\text { Plasma- } \\
\text { transferrin }\end{array}$ & Hb & $\begin{array}{c}\text { Free access } \\
\text { to food } \\
\text { Mesor amplitude }\end{array}$ & $\begin{array}{c}\text { no access } \\
\text { to food } \\
\text { Mesor amplitude }\end{array}$ \\
\hline $\begin{array}{l}\text { Liver non } \\
\text {-heme iron }\end{array}$ & -0.96 & 0.92 & 0.09 & 0.05 & 0.11 & -0.08 \\
\hline
\end{tabular}

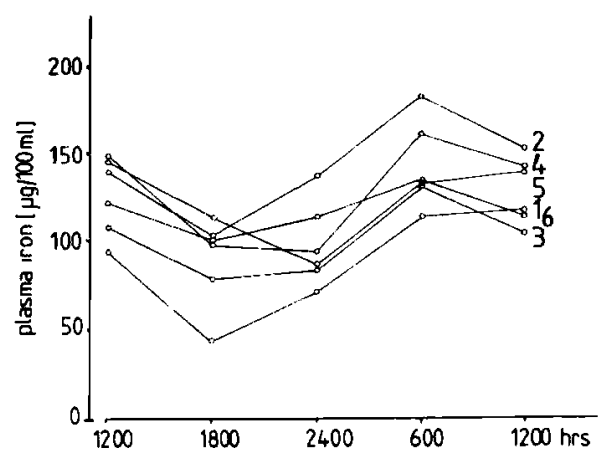

Figure 1A. $24 \mathrm{hr}$ variations in plasma iron concentration in rabbits with free access to food. (Numbers on the right ident ify the six animals).

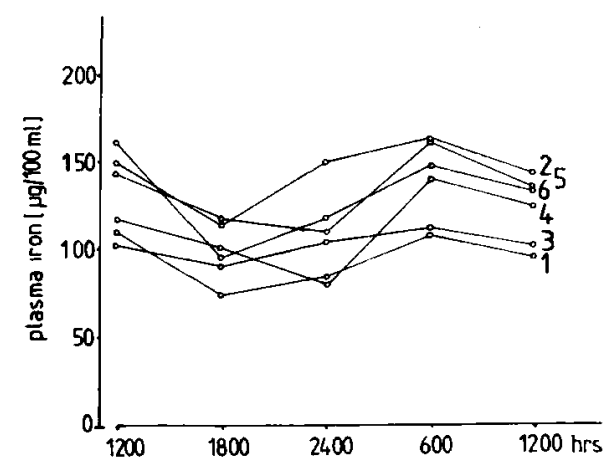

Figure 1B. $24 \mathrm{hr}$ variations in plasma iron concentration in rabbits without access to food. (Numbers on the right identily the six animals).

at noon and low levels between $1800 \mathrm{hr}$ and $2400 \mathrm{hr}$. Figure 1B shows the figures from the same animals after food deprivation. Each animal retained its individual pattern; the numbers on the right in Figure $1 \mathrm{~A} / \mathrm{B}$ identify the six animals.

By use of the single cosinor method a significant circadian variation $(P<0.05)$ could be detected in five animals under free access to food.

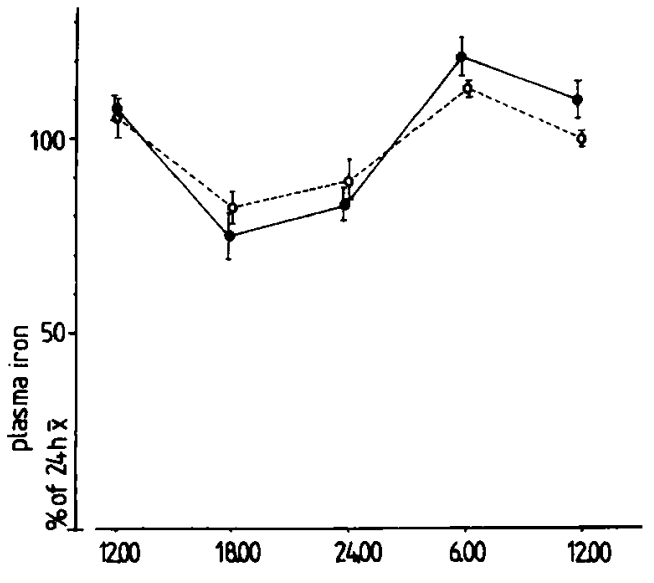

Figure 2. $24 \mathrm{hr}$ variations in plasma iron concentration, data expressed as percent of the $24 \mathrm{hr}$ mean. $(N=6, \bar{x} \pm \mathrm{S}$.E. $)$ No access to food $(100 \%=121.4 \pm 8.16 \mu \mathrm{g} / \mathrm{dl})$

$(N=30, \bar{x} \pm$ S.E. $) \bullet$ Free access to food $(100 \% 11.9 \pm 8.07$ $\mu \mathrm{g} / \mathrm{dl})(N=30, \bar{x} \pm \mathrm{S} . \mathrm{E}$.

Without food it was found in just one animal. The population mean cosinor detected a significant variation $(P<0.01)$ under free access to food with a mesor of $116.6 \mu \mathrm{g} / \mathrm{dl}$, an amplitude of 30.9 $\mu \mathrm{g} / \mathrm{dl}$, and an acrophase of $-118^{\circ}$, equivalent to $0752 \mathrm{hr}$. Without food circadian variations were also significant $(P<0.001)$. Compared to the fed condition the mesor did not change $(118,1 \mu \mathrm{g} / \mathrm{dl})$ nor did the acrophase $\left(-112^{\circ}=0728 \mathrm{hr}\right)$ but a decrease in amplitude to $22.3 \mu \mathrm{g} / \mathrm{dl}$ was observed $(P<0.05,1$-test $)$. When expressed as $\%$ of the $24-$ hr-mean the six animals showed a range between $75.4 \%$ and $122.4 \%$ under free access to food and between $82.2 \%$ and $113.6 \%$ without access to food (Figure 2). An ANOVA of this data was significant in the starved animals only $(P<0.001)$.

Plasma transferrin (Figure 3) did not vary significantly within $24 \mathrm{hr}$ under free ascess to food (24 hr mean: $2.84 \pm 0.24 \mathrm{mg} / \mathrm{ml}, n=30$, 


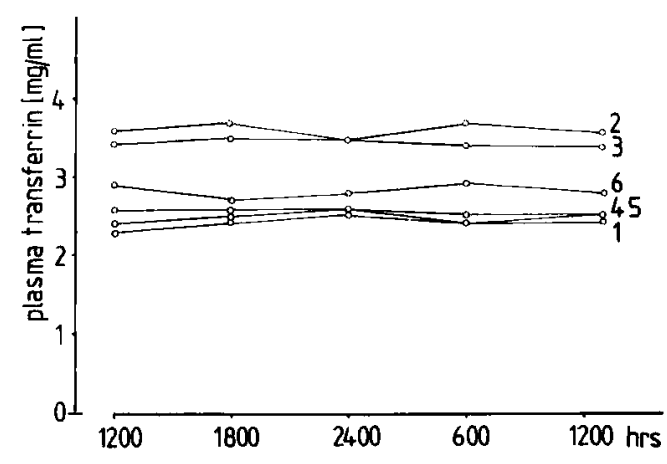

Figure 3. $24 \mathrm{hr}$ variations in plasma transferrin. $24 \mathrm{hr}$ mean: $2.83 \pm 0.24 \mathrm{mg} / \mathrm{ml},(N=30, \vec{x} \pm$ S.E.) (Numbers on the right identify the six animals).

$\bar{x}=$ S.E.; circadian range: $99.6-100.7 \%$ of the 24 $\mathrm{hr}$ mean). The free iron binding capacity of the plasma showed $24 \mathrm{hr}$ variations inversely correlated to those of plasma iron (investigated in two animals, results not shown).

\section{Discussion}

In plasma over $95 \%$ of iron is bound to transferrin. Therefore, plasma transferrin has to be considered when looking at parameters which possibly influence the circadian behaviour of plasma iron. However, no $24 \mathrm{hr}$ variation of plasma transferrin was observed (Figure 3). The circadian variations of plasma iron are thus supposed to modulate the free iron binding capacity of a constant amount of plasma transferrin. Indeed, this was described for men (9) and rabbits (16) and comparable values were found in two animals in this study. Transferrin has a $t_{1 / 2}$ of about 3.5 days (17). Therefore, no dependence of transferrin plasma concentration on a circadian pattern of synthesis of metabolization of this protein could be expected.

Body iron stores were individually characterized by liver non-heme iron, haemoglobin and plasma transferrin concentrations. The range of liver non-heme iron concentration and the comparison of haemoglobin and plasma iron values with the literature (16) show, that there was a varying degree of iron deficiency in the six animals, although they were fed on a sufficiently iron substituted diet for 4 weeks prior to the experiments. The necessity for control of these data is thus underlined for studies dealing with iron-absorption and ferrokinetics. As expected (18) liver non-heme iron, haemoglobin and plasma transferrin concentrations were well correlated among each other. On the other hand, these parameters did not show any significant correlation with the circadian mesor and amplitude of plasma iron (Table 2).

In animals without access to food a significant circadian plasma iron variation was demonstrated. The most likely cause of this phenomenon is a circadian variation in the exchange between plasma iron and the much bigger iron compartments, e.g. iron-stores, erythron, functional iron. In rats $24 \mathrm{hr}$ variations in reticulo-endothelial iron release af ter phagocytosis of ${ }^{59} \mathrm{Fe}$ labeled erythrocytes coincide with the $24 \mathrm{hr}$ variations in plasma iron (19).

When free access to food was compared to food deprivation a significant influence $(P<0.05)$ of food intake on the amplitude of 24 hr variations of plasma iron became evident $(30.9 \mu \mathrm{g} / \mathrm{dl} \vee 22.3 \mathrm{ug} / \mathrm{dl})$. The circadian rhythm present in animals without access to food is thus amplified by food-iron. Caecotrophy (excretion and reingestion of highly digestible caecal content) was not prevented in this study, which implies that caecal contents were recirculated. In animals prevented from caecotrophy, even greater differences in the amplitude of circadian plasma iron variations should be expected between starved and fed animals. The increase in interindividual variation under free access to food in this study may be explained by large interindividual differences in the circadian feeding patterns, that were reported for rabbits (21), but were not determined in this study. The relatively small circadian amplitude in plasma iron concentrations in rabbits as compared to larger variations reported for humans may at least partly be explained by the different feeding pattern of the two species: $3-5$ meals during the active span in men versus $20-30$ meals in the rabbit, which are more evenly distributed over 24 hr (21). 
The diet used in this study leads to an estimated absorption of $3,6 \mu$ mole $\mathrm{Fe} / 24 \mathrm{hr} / \mathrm{kg}$ body weight $(40 \mathrm{~g}$ food intake $/ 24 \mathrm{hr} / \mathrm{kg}$ body weight, $10 \%$ absorption, caecotrophy neglected) which would cause an increase in plasma iron of $320 \mu \mathrm{g} / \mathrm{dl}$ (blood vol. $=7 \%$ of body weight, $\mathrm{Hk}$ $40 \%$ ). As the amplitude of circadian plasma iron variations under free access to food is only 30.9 $\mu \mathrm{g} / \mathrm{dl}$, this is evidence for a rapid distribution of absorbed iron into the other iron compartments. Circadian variations in the bioavailability of oral iron compounds can therefore hardly be measured by comparison of $24 \mathrm{hr}$ plasma iron variations as performed by Tarquini et al. (20). It remains to be elucidated, whether in his study the difference in plasma iron concentration after oral iron application were caused by an increase in iron absorption or rather by changes in iron distribution.
A circadian variation of serum iron concentration was also described by Fox et al. in nightactive rabbits, which, however, is $180^{\circ}$ out of phase to the results of this study. On the other hand, the circadian variation of this study is in phase with circadian serum iron concentrations in man (day-active) (7). Fox et al. kept thier rabbits in outside hutches, whereas our animals were kept inside the institute. Since rabbits are very sensitive to noise as zeitgebers (21), the circadian system of our animals might have been synchronized to the human rest/activity cycle.

This study demonstrates in rabbits a circadian rhythm in plasma iron levels under food deprivation, the amplitude of which is increased by food intake. Comments on the mechanism and regulation of $24 \mathrm{hr}$ plasma iron variations under starvation, however, are beyond the scope of this investigation.

\section{References}

1. Heilmeier L. and Ploetner K. Das Serumeisen und die Eisenmangelkrankheit. Fischer, Jena 1937.

2. Höyer, K. Physiologic variations in the iron content of human blood serum-I. The variations from week to week, from day to day and through 24 hours. Acta Med Scand 69, 562-576, 1944.

3. Valquist B. Das Serumeisen. Acta paed. 28 (Suppl. 5), 1941.

4. Höyer K. Physiologic variations in the iron content of human blood serum-II. Further studies on the intra diem variations. Acta Med Scand 69, 577-585, 1944.

5. Schäfer K-H. Boenecke-I. Die neurovegetative Lenkung des Eisenstoffwechsels. Arch exp Path Pharmakol 207, 660-687, 1949.

6. Sinniah R, Doggart J. R. and Neill D. W. Diurnal variations of the serum iron in normal subjects and in patients with haemochromatosis. Br J Haem 17, 351-358, 1969.

7. Hamilton L. D., Gabler C. J., Cartwright G. E. and Wintrobe, M. M. Diurnal variation in the plasma iron level of man. Proc Soc Exp Biol 75, 65-68, 1950.

8. Paterson J. C. S., Marrack D. and Wiggins H. S. Hypoferraemia in the human subject: The importance of diurnal hypoferraemia. Clin Sci 11, 417-423, 1952.

9. Bowie E. J. W., Newlon Tauxe W., Sjoberg W. E. and Yamaguchi M. Y. Daily variation in the concentration of iron in serum. Am J Clin Path 40, 491-494, 1963.

10. Wiltink W. F., Kruithof J., Mol C., Bos G. and VanEijk H. G. Diurnal and nocturanl variations of the serum iron in normal subjects. Clin Chim Acta 49, 99-104, 1973.

11. Lynch S. R. Iron. In: Solomons N. W. and Rosenberg I. H., eds Current Topics in Nutrition and Diseases, Vol, 12: Absorption and Malabsorption of Mineral Nutrients. Allan R. Liss, New York pp 89-124 (1984).

12. Milder M. S., Cook J. and Finch C. A. Influence of food iron absorption on the plasma iron level in idiopathic haemochromatosis. Acta Haemat 60, 65-75, 1978.

13. Bauer W., Sunday S., Huebers H. and Finch C. A. The relationship between plasma iron and plasma iron turnover in the rat. Blood 57, 239-342, 1981.

14. El-Shobaki F. A. Studies on iron utilization in vitro and in vivo. Ph.D.-thesis, Faculty of Science, University of Cairo, 1970.

15. Cornelissen G., Halberg F., Stebbings J., Halberg E., Carandente F. and Hsi B. Chronobiometry with pocket calculators and computer systems. La Ricerca 10,355-385, 1980.

16. Fox R. R., Laird C. W. and Kirshbaum J. Effect of strain, sex, and circadian rhythm on rabbit serum bilirubin and iron levels. Proc Soc Exp Biol Med 145, 421-427, 1974.

17. Regoeczi E. and Hatton M. W. C. Transferrin catabolism in mammalian species of different body sizes. Am J Physiol 238, R 306-R 310, 1980.

18. Osterloh K., Schümann K., Ehtechami C. and Forth W. Transferrin in isolated cells from rat duodenum and jujunum. Blut 51, 41-47, 1985 . 
19. Lynch S. R., Simon M., Bothwell T. H. and Charlton R. W. Circadian variations in plasma iron concentration and reticuloendothelial iron release. Clin Sci Mol Med 45, 331-336, 1973.

20. Tarquini B., Romano S., de Scalzi M., de Leonardis V., Benvenuti F., Chegai E., Comparini T., Moretti R. and Cagnoni M. Circadian variations of iron absorption in healthy human subjects. In: Reinberg A. and Halberg F. eds., Advances in the Biosciences Vol. 19. Chronopharmacology. Pergamon Press, Oxford, pp. 347-354, 1979.

21. Jilge $B$. The circadian periodicity of the rabbit during a light-dark regimen, cont inuous light conditions, and restricted food access. Dtsch Tierärzul Wschr 94, 18-23, 1987. 